\title{
The Invisible Feminist Action of Roma Families
}

Affilia: Journal of Women and Social Work

I-17

(C) The Author(s) 2020

Article reuse guidelines: sagepub.com/journals-permissions DOI: $10.1177 / 0886109920906780$ journals.sagepub.com/home/aff

(S)SAGE

\author{
Ariadna Munté Pascual' ${ }^{\circledR}$, Irene de Vicente', \\ Virginia Matulic', and Jelen Amador'
}

\begin{abstract}
In this article, we analyze the role of Roma families in shaping the paths of academic success of Roma women (hereinafter, the Romí). Our findings challenge biased views of Roma culture as a reproducer of gender inequality, which is assumed to be higher among the Roma than in other cultures. Recent advancements in the field of cultural and feminist studies show the role of Romí as agents of change in gender relations, which contributes to overcoming a stereotype that tends to hierarchically classify cultures as less or more unequal with regard to gender relations. This research includes Romí voices and concludes that family support in academic careers is a way of transforming gender relations within the Roma community. This study is based on the dialogical feminism and contributes to the acquisition of cultural competences about Romí among social workers, which may have a positive impact in the social work practice and the overcoming of stereotypes about this community.
\end{abstract}

\section{Keywords}

academic success, educational quality/equity, family, Roma women

Until now, some studies have reinforced a biased view of the Roma culture as a culture that reproduces gender inequality more than in others (Crespo, 2002; Pérez de la Fuente, 2008). These studies have mostly been conducted without the participation of the Roma in the process of knowledge creation, which may produce ethnocentric bias that perpetuates negative stereotypes (Touraine et al., 2004) and constitutes a form of symbolic violence against Roma, which occurs when a whole community is stereotyped (Sierra \& Rio, 2017).

The stereotypes about the Roma culture have influenced educational practices addressed to Romí girls, favoring segregation in schools and reproducing inequalities (Flecha, 2015). More recently, feminist scholars have challenged ethnic biases against Roma by showing that Romí are agents of change in gender relations (Garcia, 2015). According to this shift in feminist studies, Romí show that their participation in education may increase the academic expectations of Roma children, moving

\footnotetext{
'University of Barcelona, Spain

Corresponding Author:

Ariadna Munté Pascual, Social Work Training and Research Section, Faculty of Education, University of Barcelona, Passeig de la Vall d'Hebron, I7I, 08035 Barcelona, Spain.

Email: amunte@ub.edu
} 
beyond society's stereotypes toward the Romí (Melgar et al., 2011). However, the inclusion of feminist perspectives into Roma research and the ways to include their voices is still an underresearched topic.

In this article, we present the results of a study in which the objective is to analyze the role of families in the paths of academic success of the Romí from a feminist perspective. This objective is in line with an emerging approach that includes all women's voices into feminist research, also those traditionally excluded from feminist academic discussions. The evidence presented and discussed shed light on the concrete case of the Romí in Catalonia (Spain). The results show the impact that the actions of families have had in the academic trajectories of the Romí and how our interviewees have used education to transform gender relations. This study is conducted mainly in Catalonia (Spain) because of the presence of Romí facing inequalities in this region, the existence of Romí networks of feminist solidarity, and the previous work of the researchers about the Roma population in Catalonia based on dialogical feminism. The results could be potentially useful to other contexts because of the transnational nature of the Roma people, who see themselves as a people without territory living in different continents, although they are mostly located in Europe (Sordé et al., 2013; Torres, 1987).

\section{The Roma Community in Europe and Spain}

The Roma is an ethnic minority of approximately 12 million people, distributed geographically in America, some areas of Asia and Oceania, and Europe. An estimation indicates that 10 of the 12 million Roma are in Europe (European Union Agency for Fundamental Rights, 2018). Research shows that the origin of the Roma is the region of Punjab in India (Sordé, 2006), and the exodus and expansion of the Roma people to Europe started because of violent invasions, being throughout history a persecuted community. The current inequalities affecting Roma population in Europe have been analyzed by the European Union Agency for Fundamental Rights (2018), presenting data about the Roma situation in five areas: (1) education, (2) poverty, (3) occupation, (4) health, and (5) discrimination, harassment, and hate crimes. In education, $48 \%$ of minors with an age corresponding to the second cycle of secondary education do not study. In Spain, the employment insecurity and temporality of Roma are common because they tend to occupy jobs requiring low educational levels (Fundación Secretariado Gitano, 2012). In health, Roma have higher percentages in chronic diseases and lower life expectancy if compared with non-Roma population (Martín-Pérez et al., 2015), and in education, Romí girls drop out of primary school and do not finish secondary education much more than non-Romí girls (6\% Romí girls and 63\% non-Romí girls; Melgar et al., 2011).

\section{Romí: Stereotypes in Mainstream Societies}

Different disciplines have approached the concept of stereotype with similar understandings, for instance, in psychology (Colman, 2014) or sociology (Turner, 2006). Through oversimplified generalization, stereotyping social groups implies reducing the characteristics of "the other," who are different from "us" in unfavorable terms. The reproduction of stereotypes influences the views that the mainstream society has about the Romí in diverse social spheres, for instance, education. In the case of Roma, Hancock (2002) used the concept of anti-Gypsysm to refer to the stereotypes perpetuated negatively against Roma people. Some negative images have been generated over the centuries about the Roma, which are reinforced by the media (Kroon et al., 2016; Tremlett, 2014). These negative images perpetuate stereotypes, such as illegal occupation in housing, crime, and coexistence problems (Peeters, 2005).

The diverse stereotypes about the Romí resonate with the concept of intersectionality, understood as the structural consequences resulting from the interaction between two or more forms of discrimination or subordination systems (United Nations World Conference Against Racism, 2001). 
Particularly, intersectionality refers to the forms in which racism, patriarchy, economic inequalities, and other discriminations contribute to create and consolidate inequalities influencing the positions of women, among others. Furthermore, it is important to mention the role of Black Feminism (Crenshaw, 1989) in relation to intersectionality and the ways it influences the role of women, particularly the most excluded of the feminist discourses. In the case of the Romí, the intersectionality implies the existence of discrimination because of gender and culture, both reinforced by stereotypes showing Romí sometimes portrayed as stealers of babies or practitioners of witchcraft (Woodcock, 2010).

\section{Education, Gender, and Family}

The European Commission (2010a) identifies the Roma and women as two out of nine groups with a greater risk of social exclusion. On average, about $20 \%$ of Roma respondents across 11 European Union member states are not covered by medical insurance or do not know if they are (European Union Agency for Fundamental Rights, 2012). Research has also demonstrated the barriers for Roma in the health system (Aiello et al., 2018) and in education. According to United Nations Educational, Scientific, and Cultural Organization data (2010), 50\% of Roma children do not complete primary education. Presence of Roma in higher education is also lower across the Member States when compared with non-Roma population (European Union Agency for Fundamental Rights and United Nations Development Programme, 2011; Hinton-Smith et al., 2017). This is certainly the case in Spain where the presence of the Roma population in higher education is very low: Although there is a lack of updated statistical data in Spain, Padilla et al. (2017) refer to the work of Laparra (2007) to inform that between $0.3 \%$ and $1.1 \%$ of the Roma population had university degrees compared to the Spanish population at $22.3 \%$.

Discrimination affects Romí because of the intersection of ethnicity and gender. Women experience gender-based discrimination globally, but in the case of the Romí, this intersects with racial and cultural discrimination based on Roma identity, manifested in segregation in schools. The social imagery on the Roma in relation to education includes the image of an endogamous group that rejects the culture of the mainstream society. As a consequence, it is wrongly assumed that Roma do not want to educate their minors for fear of acculturation. Some research developed without including Roma voices concludes that the disadvantage of the Roma in education is due to their cultural features (Brügemann, 2014). In Spain, the reproduction model in education, which states that education is not responsible for inequalities and does not change them, prevailed until the 1990s (Aubert et al., 2004), contributing to perpetuate stereotypes. The study of authors as Enguita (1999) or Cavalli-Sforza \& Cavalli-Sforza (1994) are examples of this model.

Although such contributions were produced in the 1990s, they have influenced the training of professionals working with vulnerable populations in Spain, reproducing stereotypes about the Roma. The contributions of the reproduction model come from supposedly experts, favoring segregationist policies in schools and generating very low expectations of Roma students. On the contrary, research suggests that the Roma overcome racism achieving academic success (DROMIN, 2008-2011; Díez et al., 2018; INCLUD-ED, 2006-2011; WORKALÓ, 2001-2004). The role of Roma families to support the Romí in higher education and the relevance to make visible Romí with successful trajectories in higher education have been analyzed (Sánchez, 2005), also in Catalonia (García et al., 2019). Some research addresses the education of the Romí by showing how some Romí achieve basic and even higher education levels because of three factors: personal effort, support and encouragement of their families, and establishment of trusted links with people from the educational environment, such as teachers or social workers (Reimer, 2016). Reimer shows that academic Romí become models for other women (and also for men and families) by achieving higher education. Similarly, the "Roma Women Research-Report on Spain" shows that Romí 
would like university studies for their children (Segovia, 2016). In the case of immigrant Romí, some research shows that the schooling of their children was one of their priorities and that they wished they also could have studied to have better living conditions. Some immigrant Romí expressed the relevance of education, especially in the case of Roma girls, and describe family stories of support, resonating with some of the narratives of change of the Chicano/a Movement to fight for equality and acceded to quality education in the 1960s and 1970s (Lechuga-Peña \& Lechuga, 2018).

\section{Feminism and Roma Feminism}

The feminist movement has included discriminatory processes because of ethnicity, class, or other personal conditions. Scholars such as bell hooks (1984) claimed that those women traditionally excluded from feminist theory should have a voice in feminism, for instance, women in a lower class or non-white. Moreover, the contributions about the cultural diversity in feminism have increased, including indigenous feminism (Chilisa \& Ntseane, 2010) or Islamic feminism (Moghadam, 2002), and the need to advance in social work from feminist perspectives (Gringeri et al., 2010). In line with these approaches, the dialogical feminism (De Botton et al., 2005) is based on the inclusion of the voices of "other women," that is, women with no academic background, who struggle for gender equality without social recognition. The dialogic feminism facilitates research in which the capacity of the Romí demonstrates its relevance to overcome the stereotyping trends of the mainstream societies (Garcia, 2015). Brooks (2012) denounced the gender equality movement that traditionally spread the stereotype that Roma culture is more sexist than the mainstream cultures. This position implies that non-Roma feminists have had a supposed superiority and consider themselves to be a model to be followed in the emancipation process of the Romí without listening to their needs, much less recognize their active role in the advancement toward gender equality. In this sense, Brooks urges not only the main feminist leaders but also the Romí to further develop Roma feminism, expanding its possibilities for social transformation.

Oprea (2004), a Roma feminist activist, denounced a form of discrimination from the traditional feminism that does not consider the needs of Roma women. There is the stereotype that Roma culture is more sexist than other cultures and that the Romí accept gender-based violence and the discriminatory treatment of men in their community. This stereotype is explained due to cultural issues, which assumes that Romí would not be interested in feminism. Traditional feminism has advanced without including the Romí in the feminist struggle. Oprea shows that nonacademic Roma feminism exists, and in fact, the advancement of feminism that is led by anonymous Romí and men becomes visible through the actions that are performed by the associations and federations of the Romí, such as Drom Kotar Mestipen Association, the Federation of Association of Romí KAMIRA, and the European Romí's Movement-International Romí's Network. In line with these developments, it is important to emphasize the creation of networks at the international level that specifically addresses gender equality and Roma feminism.

\section{Method}

\section{Communicative Methodology Design}

The communicative methodology implies an "egalitarian dialogue among researchers and the people involved in the communities and realities being studied," and it is based on the idea that everyone can contribute to the construction of knowledge (A. Gómez et al., 2011). It may differ from other methodologies as it has demonstrated to enable research with vulnerable populations that achieve social impact (A. Gómez et al., 2019). Two criteria underline the selection of the communicative 
methodology to develop this qualitative study: (1) the social impact achieved in previous research with Roma using this methodology (Aiello et al., 2013; Flecha, 2014; Soler, 2017) and (2) the recognition by the European Commission as a methodology suitable to work with vulnerable communities (European Commission, 2010b). A central feature of the communicative methodology is that it enables an egalitarian dialogue between "scientists" and "non-scientists," which results in a shared construction of knowledge (Gomez et al., 2006; A. Gómez et al., 2011). With this approach, researchers should provide scientific knowledge, and the Roma participants contribute with their experiences, trajectories, reflections, and ways of life to cocreate knowledge. Therefore, the research based on the communicative methodology does not develop research about the Roma but with the Roma. Some studies such as the ones developed by Vargas and Gómez (2003) and A. Gómez et al. (2019) indicate the acceptance of this methodology by the Roma community because of the inclusion of the background (from the world of life) throughout the process of scientific production and because of the objective of improving the social situation of the Roma people in this type of research:

Communicative techniques require going back to each person in the study to continue the dialogue, in order to better capture shared interpretations of reality and avoid partial and possibly inaccurate explanations of the situation and solutions for the Roma. The idea is not to seek approval but to generate knowledge together (Gómez \& Vargas, 2003, p. 377).

The team that developed this research was composed of four researchers, including a Roma researcher. The non-Roma researchers were women and white, with social work as a main field of knowledge. Additionally, they have backgrounds in anthropology, sociology, and education. They have extensive expertise in the communicative methodology and the ways to cocreate knowledge with vulnerable groups, particularly with Roma, women, and cultural minorities. Consistent with the communicative methodology, the results were presented to discuss with the participants and ensure greater veracity in the interpretations and conclusions of the research team. In the conversations, especially two of the participants refined some of the words and assertions to accurate the analysis. Therefore, the second round with the participants resulted in a dialogical process to reach final agreements with the ideas expressed.

The communicative approach includes the following qualitative techniques: daily-life stories, focus groups, and observations (A. Gómez et al., 2011). This study focuses on the experiences of Roma in relation to higher education as part of the life course, and therefore, the research team discussed the most appropriate communicative technique and agreed to develop daily-life stories, as it allowed to have the overall narrative about the biography of each participant. The communicative daily-life story is defined as follows:

A dialogue between the researcher and the research subject oriented to reflect on and interpret the daily life of a social actor. Unlike other types of life stories, the communicative daily-life story aims not to construct a biography of the research participant but instead to elicit a very reflective narrative of her or his daily life that sheds light on the important events, present and past, and reflections as well as future expectations (A. Gómez et al., 2011, p. 240)

\section{Data Collection}

A total of four communicative daily-life stories were developed, recorded, anonymized, and analyzed. As the number of daily-life stories is limited to four, the type of conclusions are emerging insights that could be further explored in the future, including a more in-depth research specifically addressed to family members. The stories were conducted between 2017 and 2018. Three were 
Table I. Profile of the Participants in the Study.

\begin{tabular}{|c|c|c|c|c|}
\hline $\begin{array}{l}\text { Pseudonym } \\
\text { and Code }\end{array}$ & Age & Origin & Studies & Family History and Current Situation \\
\hline Rima R_E & 34 & $\begin{array}{l}\text { United } \\
\text { States }\end{array}$ & $\begin{array}{l}\text { University degree } \\
\text { in education and } \\
\text { dance (United } \\
\text { States). PhD in } \\
\text { history of art }\end{array}$ & $\begin{array}{l}\text { She was the youngest child of a single-parent family with } \\
\text { three children (two boys and one girl). The mother was } \\
\text { illiterate and an immigrant to the United States. Her } \\
\text { husband was violent and alcoholic. She decided to run } \\
\text { away, and for this reason, she went to the United States. } \\
\text { From that moment, her family in Spain abandoned her for } \\
\text { "leaving the family." She was abandoned by her husband } \\
\text { and was dedicated to cleaning private homes. Rima is } \\
\text { currently married and has a daughter. She lives in England } \\
\text { with her family and works at a research institute. }\end{array}$ \\
\hline Jana J_E & 26 & Spain & $\begin{array}{l}\text { University degree } \\
\text { in law. } \mathrm{PhD} \text { in } \\
\text { sociology }\end{array}$ & $\begin{array}{l}\text { She was born in a humble district of Barcelona. Her father } \\
\text { has a basic education although he has received training as } \\
\text { an evangelical pastor. She is the third of four brothers. } \\
\text { She is currently married and works as an editorial } \\
\text { assistant. }\end{array}$ \\
\hline Lidia L_E & 23 & Spain & $\begin{array}{l}\text { University degree } \\
\text { in biology and } \\
\text { master's degree } \\
\text { in neurosciences }\end{array}$ & $\begin{array}{l}\text { Because of the death of her parents, she was raised by her } \\
\text { grandparents and her aunt, with whom she still lives. } \\
\text { None of these reference adults had an education. She } \\
\text { lives in a humble neighborhood of Badalona. She is } \\
\text { currently offering private classes to students and is } \\
\text { looking for a job. }\end{array}$ \\
\hline $\begin{array}{l}\text { Janás father } \\
\text { PJ_E }\end{array}$ & 61 & Spain & Primary studies & $\begin{array}{l}\text { He comes from a very humble family. His parents did not } \\
\text { have an education. His mother was dedicated to dance } \\
\text { and secondhand sales. At the age of } 14 \text {, he finished } \\
\text { studying because of his family's economic situation. He } \\
\text { married at the age of } 18 \text { and had four children. He was } \\
\text { linked to the Evangelical Church at the age of } 22 \text { and } \\
\text { studied to be an evangelical pastor. He is currently a } \\
\text { pensioner for reasons of illness, and he acts as a pastor. }\end{array}$ \\
\hline
\end{tabular}

conducted face to face in individual settings in Spain, in places decided by the participants where it was ensured that they felt comfortable, and one was conducted online via a hangout for a Romí who was living in London. Three of four life stories involved Romí with successful academic careers, having obtained university degrees in biology, law, and history of art and one life story concerned a Roma man with a significant role within the Roma community as a gospel pastor. The Roma man was included with the aim to include a diversity of agents in the analysis. The specific profiles of the participants are identified by pseudonyms (defined by researchers) in Table 1.

The researchers used a common set of questions organized by four topics: (1) the role of families in relation to education, (2) the educational trajectories as Romí to achieve university degrees, (3) how the academic success influences the empowerment as Romí, and (4) considerations for feminism. Each interview lasted between 1 and $2 \mathrm{hr}$, and the language used was Spanish. Before the fieldwork, a detailed explanation of the research objectives was provided to the participants. The researchers also provided an informed consent form, which was duly signed and that ensured anonymity and the ethical and exclusive use of the data that were provided for the present study. 
Table 2. Categories.

\begin{tabular}{lccc}
\hline & Family & Education & Feminism \\
\hline Exclusionary dimension & 1 & 2 & 3 \\
Transformative dimension & 4 & 5 & 6 \\
\hline
\end{tabular}

\section{Data Analysis}

In line with the communicative methodology, the identification of transformative and exclusionary dimensions was at the core of the codification design. The categories of analysis were established to identify (a) the exclusionary dimension, which is related to the barriers that Romí may have that do not allow them to continue studying because of their role as women and Roma and (b) the transformative dimension, which includes those aspects that have contributed to overcome the barriers to study, including the role of families (J. Gómez et al., 2006). The concepts underlying the analysis of the categories were family, education, and feminism, and the following subthemes emerged: family well-being and improvement, family economic and social situation, single mother, rejection in school, religion in school, cultural background, solidarity among women. Table 2 summarizes the general categorization.

\section{Results}

The four participants in this study were Roma. The following vignettes introduce each of them:

Vignette 1. Lidia is 23 years old and lives in a humble neighborhood of Badalona, a municipality in the northeast of Barcelona with a total population of 217,741 . She obtained a university degree in biology and has also a master's degree in neuroscience. Their parents died when she was a child and she raised with her grandparents and aunt, with whom she still lives. Lidia is the first one in the family that has studied, and currently, she offers private classes to students and is looking for a job.

Vignette 2. Jana is 26 years old and lives in a humble district in Barcelona. She obtained a university degree in law and has a $\mathrm{PhD}$ in sociology. Her father has a basic education and has received training as an evangelical pastor. Jana is the third of four brothers. She is currently married and works as an editorial assistant.

Vignette 3. Rima is 34 years old and is originally from the United States. She obtained a university degree in education and dance and has a $\mathrm{PhD}$ in history of art. She was the youngest child of a single-parent family with three children (two boys and one girl). Her mother was illiterate and an immigrant to the United States. The husband of Rima's mother was violent and alcoholic, and she went to the United States when Rima was a child. From that moment, Rima's family in Spain abandoned her mother for "leaving the family." Rima's mother was dedicated to cleaning private homes. Rima is currently married and has a daughter. She lives in England with her family and works at a research institute.

Vignette 4. Jana's father is 61 years old and lives in Barcelona. He has primary studies and comes from a very humble family. His parents did not have an education. His mother was dedicated to dance and secondhand sales. At the age of 14, Jana's father finished studying because of his family's economic situation. He married at the age of 18 and had four children. He was linked to the Evangelical Church at the age of 22 and studied to be an evangelical pastor. He is currently a pensioner for reasons of illness, and he acts as a pastor. 


\section{The Key Role of Families}

The trajectories, social contexts, and family structure of the Romí included in this study were different. Despite the divergence in life stories, the common element is the interest of families in the studies of their daughters. Our interviewees emphasized how their relatives, such as grandparents and aunts, considered education to be the way for their daughters to have a better future. There is a commitment of Roma with the enrolment of Romí in schools, which overcomes stereotypes about the way Roma understand the role of education. This commitment becomes crucial to achieve a better life for Romí girls and therefore the possibility to support processes of social mobility. Although Roma families may live in economic deprivation, they have clear positions to prioritize education for their daughters. In our analysis, there are illustrative examples of this. Jana's father illustrates this position as follows: "My children have been enrolled in school and I have always said to them, I have always wanted them to be able to achieve something, that they could be someone" (PJ_E), and Rima told:

We were poor, but for my mother, education was the most important thing, and she sent us to a Catholic school... and when she could not pay, she cleaned the school or talked to the school director and they managed (R_E).

Higher education students may consider the possibility of working while studying for different reasons, sometimes to cover part of the costs, support their families or have own resources. However, it can happen that working while studying reduces the chances of success in achieving an academic degree. To mitigate this risk, some families tend to be supportive and prioritize the academic success of their daughters over economic aspects. Jana illustrates this as follows: "When I told my father that I would combine my studies with work, he told me that if it would be difficult for me to study, I should not do it [work]" (J_E).

Romí show their interest in education not only to acquire knowledge but also to enjoy. As a result, learning goes beyond an instrument to achieve a degree and becomes a tool to enrich themselves from the very beginning of the educational process. There is no need to pressure Romí to study or control them to do their homework, as this is something that occurs for pleasure. For example, Jana emphasized the link between her studying habits and how her parents approached the issue: "I've always been a good student... I've always liked it, and at home, I've always been pushed. They have always tried to make me see that it is important to study, training and others" (L_E). This implies that Romí challenged the stereotype that Roma children do not have an interest in their studies or aptitudes to reach certain academic levels. The analysis indicates that stereotypes can be overcome through dialogue between researchers and Romí involved in educational processes.

Another relevant issue appearing in the analysis is the stereotype of gender discrimination between Roma sons or daughters by their parents, which imply that parents prioritize education for their sons. For the participants who had brothers (Jana and Rima), they also described how they did not suffer gender discrimination from their families. On the contrary, they reached higher academic levels because of this family support and promotion, as highlighted by Jana: "My parents believed in the education of all, but the only one who took this step was me. My brothers selected other ways, such as work" (J_E). This quotation shows the effort of Jana compared with her brothers in order to continue studying. The reflection about her decision compared with her brothers can be understood as the more challenging options, thus overcoming the idea that Roma men have more options to study than Romí. Furthermore, she does not mention the barriers from her brothers to study.

The Roma identity is an issue appearing in the analysis. Sometimes, being Roma is not explained by Romí because of stereotypes of the mainstream society. This occurs also in the field of education, where the Roma cultural identity in schools is hidden in some cases. Families have a role in the 
hiding of being Roma, which can be explained by the fear of generating rejection in other students, teachers, or other community members. Such rejection may result in asking Romí girls about the Roma culture to reinforce stereotypes instead of creating high expectations in education. This is the case of Rima who explained what her mother told her since she was a child:

My mother was very private, she did not say that she was Roma ... because she was scared. Sometimes, she told me "Rima, you do not say where you come from because they are going to ask you a lot of questions and we do not have to answer and also this topic of being a Roma in the United States is very romanticized and it is also not well known (R_E).

Family support confronts the criticisms of the Roma sectors that show resistance toward education because of fear of acculturation. The importance of education is a way of maintaining culture, not of losing it. The fear to lose Roma culture can be explained by ignorance and must be confronted by giving goals to the Romí from their families. Jana's father exemplifies the fear of acculturation as follows:

There is a certain fear, they [some Roma] believe that ... it is an old mentality that comes from very far away, because there is fear that our daughters will study, go to a university, there is a certain fear, well I think it is being overcome, that now comes a new wave of people with a more open mind, ... I think it is the fear of losing your identity and there is the training ... because if you are a person with certain training you will not lose your identity, you can lose it when you do not have training or preparation because it can lead you to other contexts when you do not know very well where you come from, who you are or you are not very self- confident. Then, that is the fear that sometimes parents of daughters, especially daughters, fear them to study, to interact with other people, and to leave a circle, but I think that we have to overcome it, and I think it's coming to an end. Now I'm hearing that there are more and more young people of our ethnicity in the university, and their parents have already understood that fear has to be overcome (PJ_E).

This statement fits with the criticism that some authors have (Brügemann, 2014) the static conceptions of "culture" that have been used in the research of Roma people, which reproduces negative stereotypes. The interviewee clearly shows the ways to overcome the fear of acculturation, promoting dialogue and confidence in the Roma community. The interaction with non-Roma people appears as an aspect to be approached, supporting the idea that Romí in the university will meet other Romí students, reinforcing solidarity networks and building trust among the families.

To summarize, the reflections of the participants indicate the key role of families to overcome stereotypes about the lack of interest of Roma people in education. This is a key issue in the overcoming of Roma inequalities, as education plays a crucial role in the improvement of lives and expectations for a better future.

\section{Education and Educational Trajectory}

The feelings of loneliness can play a relevant role in the educational trajectories of Romí, taking into account that most of the students are from the mainstream society and cultural diversity is still a pending issue in Spanish universities. Jana, Lidia, and Rima express that in their cases loneliness was caused in part by the university environment, which lacked a Roma presence in all three cases. Jana explains how her fears of loneliness factored into her decision-making process of whether or not to attend university:

When I was more afraid, it was when I had to decide whether to go to university ... I had to leave my neighborhood, my friends ... fears related to leaving my neighborhood. I was not used to moving alone, to meet people from another status... And I did not know what the university would represent, the timing, or if I would lose my identity (J_E). 
It becomes essential to provide information and details about what the university is, the profiles of people studying there, the organization, and so forth, as it may help to reduce the fear that Romí express. In this sense, it is important to consider the risk of dropout of students, which is supposed to be higher than in non-Roma students.

The decision to identify themselves as Romí at university did not produce problems in their professional relationships with professors or interactions with others, although it did cause curiosity among the non-Roma people they interacted with. This was true for Lidia, who was raised by her grandparents and her aunt because of the death of her parents, none of whom had an education. In the following statement, Lidia expresses what her colleague at the university told her when Lidia explained that she was a Roma woman: She said, "until I met you, I had another image that I had of the Roma population, and it is very different, now I see how you are, I see how your family is and other families, and I see that it is very different" (L_E).

The dialogue between Romí and non-Roma students contributes to overcome the stereotypes about the Roma culture, including their visions about the role of families in supporting education. For example, a non-Roma colleague of Lidia at the university shows the change of negative images about the "other" to positive ones, building trust across cultures. Furthermore, it is important to highlight that Lidia's colleague values Lidia's family. The recognition of the change of the image of Roma's culture may result in the reinforcement of Lidiás identity.

The low socioeconomic status of our interviewee's families was a barrier to attending university because of the high costs. The possibility of obtaining scholarships through good academic performance was thus key to accessing higher education. There are examples of solidarity between nonRoma students and Romí, including the economic level and the role of scholarships. For instance, Rima explained that there was a readiness by schools to help her to reach college through economic support from the school. As Jana explained: "I have had scholarships throughout my studies: [such as] the additional financial support of the Ministry, in law studies and in the Master. I have also benefited from support from the Federation of the Roma Secretariat" (J_E).

These communicative daily-life stories show different feelings and situations linked to the overcoming of the stereotypes about the lack of interest of Roma people in education. First, the daily-life stories show the loneliness and fear that Romí may feel when leaving the immediate context - the neighborhood - to attend the university, that occurs due to perceived lack of a Roma community in Spanish universities. Second, it is important to highlight the role of interactions and dialogue between Roma and non-Roma students to dispel stereotypes, particularly with regard to Roma families. Finally, the importance of scholarship shows the overcoming of socioeconomic barriers to education, facilitating more presence of Romí in universities and thus generating transformations that change the image of the Roma as not interested in education.

\section{Academic Success, Personal Transformation, and Feminist Action}

The academic success identified in the communicative daily-life stories is linked to personal transformations with a positive impact not only at the individual level but also at the Roma community level. The acquisition of culture and status linked to the obtaining of a university degree implies a personal empowerment which benefits the Roma community. Rima reflects on this highlighting the process of transformation and the new horizons opened because of their academic studies:

I began to read and to really know the... Roma history and was really able to see that there are not only Roma in Spain but in all the world, to see that there were very few academic Roma writing history, ... this to me... something came to me. We can do something more academic, that's why we are here! I have to say that I am trained, that ... to teach people that we are not to be ignored, that we can do much more than what people believe and what we are doing. That was the beginning of starting and 
sharing the Roma pride with the public.... I have always seen how my studies opened doors and new roads ... with the master's degree, I believed it in a public way and started to declare my Roma pride more openly. Furthermore, the fear of not being "good enough" began to change ... even as an adult I have it, but now, I believe in me 100\%, and I know that everything can be achieved with work and by being very well accompanied (R_E).

The feelings of empowerment among Romí through the academic training process show the impact of education in her lives. The training awakened a desire for solidarity among the Roma people, which led all participants to develop various actions in their lives aimed at improving the situation of the Roma community, especially in expanding the educational opportunities of all Roma children. In this sense, Jana describes the following:

Since I have received a lot of support from my community, I am now indebt to them. I feel a commitment to transfer my experience to other Roma girls, to help the transformation... I participate in the Roma Association of women $(\ldots)$, that has its headquarters in the neighborhood of $(\ldots)$, where there is a lot of the Roma population. I have been voluntarily collaborating with them for years. I am also a member of the Evangelical Church of Philadelphia, which is a Pentecostal denomination, which, here in Spain, is the one that gathers the largest number of Roma people (J_E).

\section{Similarly, Rima explains that:}

My mother fought because she had to survive ... I fight for my mother, for my people, for my daughter and the daughters of others ... and I know that I have had a lot of luck ... the only thing that my mother had were her children, and I have a very full life. And I know that there are many women like my mother, and that makes me very sad ... it should not be like that, a woman should not [have to] survive [through] so many things (R_E).

The support to Romi girls to continue studying is important to promote solidarity between Romí, which is in line with recent developments in the field of gender studies analyzing how networks of support among Roma girls encourage them to continue studying. As a result, the solidarity goes beyond the neighborhood and families, as it expands to social movements. Illustrating this, Jana mentions her involvement in grassroots organizations as a facilitator to help in this endeavor. The impact of such networks of solidarity occurs at a short, medium, and long-term basis.

There is a recognition about the role of Romí as key makers of change within the Roma community. Despite the situation of discrimination of the Romí, they are a key element in the progress toward equality between the Roma people and mainstream society, and toward equality between men and women. There are clear statements in relation to the role of mothers and how they have contributed to gender equality. For instance, Rima reminds her mother's words about how a man should value her:

[Rima rephrasing her mothers' advice] Rima, you do not marry a boy that is not worth your energy. He has to value you and your voice. We can't get lost in the boy but the boy has to help my light shine brighter, not dim it. You have to work, you have to have your independence, you have to ... you never allow that a boy tells you what you have to do...(R-E).

The quotations indicate feminist positions by Rima's mother, although according to some feminist discourses, she should not be considered feminist as such by some academic scholars. The transmission of the value of being a Roma woman and the struggle toward equality without rejecting the own culture has led to the interviewees to identify themselves as feminists: "I find it practically impossible not to be a feminist being a woman and not to defend your rights" (L_E). 
However, many Romí and men who agree in the advancement toward gender equality reject the feminism that have excluded the voices of women in a lower class or non-white or with no academic background from the feminist theory. This feminism, on the one hand, does not incorporate Roma voices and on the other hand, imposes certain ideas that are contrary to Roma cultural values. This idea is described by Jana in the following quotation:

There is a feminism that does not represent all women, such as those who consider that feminism is where there are white women of a certain status or also other types that have a radical character (in feminism). For example, the other day I saw in the university a banner that read "We are all whores" or "Alone we are free." Many women do not identify with this feminism, and I do not identify with it either. In the Roma community, being a mother is not incompatible with being a university woman ... There is a part of feminism that does not respond to other contexts and other ethnic groups (J_E).

Jana's quotation is in line with the feminism of the "other women," those women usually excluded from the mainstream feminist discourse (De Botton et al., 2005). The feminism of the "other women" claims for the inclusion of all women voices in the feminist discourses, placing cultural diversity at the core of the debates (De Botton et al., 2005).

The existence of a Roma feminism in which men and women get involved is identified in the communicative daily-life stories. Jana summarizes in these words this thought:

The association where I work, we work for that, to get Roma feminism. The woman is the engine of change for the Roma people... From the association, we are finding a lot of disposition of Roma men who collaborate so that the women study. They take care of the children. There is very good disposition. The men know that Romí are leading a change (J_E).

There is a recognition that the agents of change in the Roma community are the women, placing them at the core of social transformation. This is also possible because of the support Romí have from Roma men, which implies to join efforts toward social change. At the same time, this analysis provides evidence to overcome the stereotype about the Roma as a nondynamic culture. The respect of Roma men to Romí leading change underlines the change in gender relations.

To sum up, the analysis of the interviewees demonstrates that the academic trajectories of Romí could imply a personal transformation in dialogue with other university students, overcoming stereotypes about Roma and the ways to be part of feminist action.

\section{Discussion}

Our results showed the importance of family support for our interviewees, who were highly educated Romí, which is consistent with previous studies (DROM-IN, 2008-2011; INCLUDED, 2006-2011). We argued that this family support for education was central to transforming gender relations within the Roma community. In sharing their life stories with us, our interviewees highlighted the role of female figures who appeared as promoters and/or facilitators of their successful academic trajectories. Through their voices and through dialogue, they have contributed to advance toward more inclusive feminism in line with the dialogical feminism (De Botton et al., 2005).

The Romí, sometimes without identifying themselves as feminists, in their actions of everyday life have contributed significantly to the path toward gender equality within the Roma community. Through the education of their children, the Romí have been creating more egalitarian relationships that have allowed men to support their daughters in their studies. This evidence contributes to 
overcoming stereotypes about the Roma community that tend to perpetuate negative images of a cultural group, in this case reinforcing anti-Gypsysm as defined by Hancock (2002).

Regarding the participants of this research, their daily-life stories show how the achievement of higher education has opened an entire universe of knowledge while providing them with confidence. They demonstrate that the reproduction model in education does not represent their social and personal transformations (Aubert et al., 2004). The three respondents express that access to university studies has empowered them and made them more aware of ethnic and gender inequality. This awareness has generated a desire to contribute to the transformation of the Roma people, especially due to the double inequality in their lives. Thus, through different social actions and through their private lives they contribute to build a path toward gender equality within the Roma community and ethnic equality in mainstream society.

The Romí participating in this study provide relevant insights into the role of feminism in their lives. It is important to emphasize that one of the participants identify themselves as feminist, although rejecting the traditional trends of feminism. Another participant speaks of the emergence of a Roma feminism from the association movement of Romí-one that has existed in families for decades.

\section{Conclusion}

The results have important implications for social work practice. The literature in social work has shown that cultural competency among social workers is needed (Berg, 2014) and can influence their practice in a positive manner (Jani et al., 2016; Weaver, 1999). Stereotypes about the Roma people can contribute to a lack of competence among non-Roma social workers and to the design of programs that are not aligned with their needs. The idea that Roma people are not interested in education or that Romí are more likely to see themselves as "less" than men can negatively influence social work practices, as a result of the stereotypes.

The research design of this study was based on the communicative methodology (A. Gómez et al., 2011), which has been used in previous research on the Roma community (Aiello et al., 2013; Flecha, 2014; Soler, 2017). The interactions between the research team and participants in the study have allowed two-way dialogues, favoring the cocreation of knowledge and enriching the research process. The concrete case of the Romí requires analysis with methodologies that include their views and needs in order to overcome gender and cultural stereotypes. The use of the communicative methodology in this study is in line with this need and provides evidence on how to design a research process that includes the voices of some of the most excluded, the Roma women.

This research has some limitations to be considered. The number of respondents is small because of the qualitative nature of the study, and the possibilities to replicate this kind of research require the identification of successful academic trajectories of Romí. The insights of the participants could be further explored with additional qualitative techniques, being this study limited to daily-life stories. However, this article provides evidence of Romí trajectories that challenge stereotypes about their capabilities, allowing social workers to have examples of change of Romí and their families, promoting also changes in the practices of social work and related social policies. High expectations about Romí can achieve a positive impact not only for the Romí but also for those dedicating their work to supporting stories of change.

To conclude, this study has shown the relationship among family support, academic success, and Romí. Only the inclusion of the voices of Roma in the studies on any Roma question can bring the transformative potential of the Roma people toward a fairer society with more solidarity. 


\section{Authors' Note}

Jelen Amador is now affiliated to Autonomous University of Barcelona, Spain.

\section{Declaration of Conflicting Interests}

The author(s) declared no potential conflicts of interest with respect to the research, authorship, and/or publication of this article.

\section{Funding}

The author(s) received no financial support for the research, authorship, and/or publication of this article.

\section{ORCID iD}

Ariadna Munté Pascual (D) https://orcid.org/0000-0002-2226-634X

\section{References}

Aiello, E., Flecha, A., \& Serradell, O. (2018). Exploring the barriers: A qualitative study about the experiences of mid-SES Roma navigating the Spanish healthcare system. International Journal of Environmental Research and Public Health, 15(2), 377. https://doi.org/10.3390/ijerph15020377

Aiello, E., Mondejar, E., \& Pulido, M. A. (2013). Communicative methodology of research and recognition of the Roma people. International Review of Qualitative Research, 6(2), 254-265. https://doi.org/10.1525/irqr. 2013.6.2.254

Aubert, A., Duque, E., Fisas, M., \& Valls, R. (2004). Dialogar y transformar. Pedagogía crítica del siglo XXI. Graó.

bell hooks (1984). Feminist theory: From margin to center. South End Press.

Berg, K. K. (2014). Cultural factors in the treatment of battered women with privilege domestic violence in the lives of white European-American, middle-class, heterosexual women. Affilia: Journal of Women and Social Wor $k, 29(2), 142-152$. https://doi.org/10.1177/0886109913516448

Brooks, E. (2012). The possibilities of Romani feminism. Signs, 38(1), 1-11. https://doi.org/10.1353/ren.2008. 0050

Brüggemann, C. (2014). Romani culture and academic success: Arguments against the belief in a contradiction. Intercultural Education, 25(6), 439-452. https://doi.org/10.1080/14675986.2014.990229

Cavalli-Sforza, L., \& Cavalli-Sforza, F. (1994). ¿quiénes somos?. Historia de la diversidad humana. Editorial Crítica.

Chilisa, B., \& Ntseane, G. (2010). Resisting dominant discourses: Implications of indigenous, African feminist theory and methods for gender and education research. Gender and Education, 22(6), 617-632.

Colman, A. (2014). A dictionary of psychology. Oxford University Press. https://www.oxfordreference.com/ view/10.1093/acref/9780199534067.001.0001/acref-9780199534067

Crenshaw, K. (1989). Demarginalizing the intersection of race and sex: A black feminist critique of antidiscrimination doctrine, feminist theory and antiracist politics. University of Chicago Legal Forum, 1(8), $139-167$.

Crespo, I. (2002). Cambio cultural y desarrollo humano en contextos minoritarios el papel de la mujer en una comunidad gitana [Doctoral dissertation]. UAB.

De Botton, L., Puigvert, L., \& Sánchez, M. (2005). The inclusion of other women: Breaking the silence through dialogic learning. Springer.

Díez, J., Sanmamed, A. F. F., García, R., \& Molina, S. (2018). Pathways to equitable and sustainable education through the inclusion of Roma students in learning mathematics. Sustainability, 10(7), 2191.

DROM-IN. (2009-2011). Inmigración gitana en España: los retos de la inclusión social y la convivència. Barcelona: Plan nacional de I+D+I, ministerio de ciencia e innovación. Barcelona, GEDIME-universitatautònoma de Barcelona (UAB). 
European Commission. (2010a). The European platform against poverty and social exclusion: A European framework for social and territorial cohesion. Communication from the commission to the European parliament, the council, the European economic and social committee and the committee of the regions, 2010. SEC(2010), 1564 final.

European Commission. (2010b, April 8-9). Conclusion on conference science against poverty. Segovia, Spain.

European Union Agency for Fundamental Rights. (2012). The situation of Roma in 11 EU member states survey results at a glance. Publications Office of the European Union. https://fra.europa.eu/sites/default/files/fra uploads/2099-FRA-2012-Roma-at-a-glance_EN.pdf

European Union Agency for Fundamental Rights (2018). A persisting concern: Anti-gypsyism as a barrier to Roma inclusion. https://fra.europa.eu/en/publication/2018/roma-inclusion

European Union Agency for Fundamental Rights and United Nations Development Programme. (2011). The situation of Roma in 11 EU member states. United Nations Development Programme, World Bank and European Commission. http://issuu.com/undp_in_europe_cis/docs/_roma_at_a_glance_web/1\#download

Fernández Enguita, M. (1999). Alumnos gitanos en la escuela paya: Un estudio sobre las relaciones étnicas en el sistema educativo. Ariel Practicum.

Flecha, R. (2014). Using mixed methods from a communicative orientation: Researching with grassroots Roma. Journal of Mixed Methods Research, 8(3), 245-254. https://doi.org/10.1177/1558689814527945

Flecha, R. (2015). Successful educational action for inclusion and social cohesion in Europe. Springer.

Fundación Secretariado Gitano. (2012). Informe anual 2011. https://www.gitanos.org/upload/43/97/FSGme moria011.pdf

Garcia, T. (2015). Contribuciones de la mujer gitana a la ciencia, a las políticas y a la mejora social. Multidisciplinary Journal of Gender Studies, 4(3), 832-855. https://doi.org/10.4471/generos.2015.1721

García, T., Santiago, D., \& García, M. (2019). Designing and implementing public policies with and for Roma people. The social impact of the integrated plan for the Roma in Catalonia. International Journal of Roma Studies, 1(1), 84-119. https://doi.org/10.17583/ijrs.2019.3957

Gómez, A., Padrós, M., Ríos, O., Mara, L. C., \& Pukepuke, T. (2019). Reaching social impact through communicative methodology. Researching with rather than on vulnerable populations: The Roma case. Frontiers in Education, 4(9). https://doi.org/10.3389/feduc.2019.00009

Gómez, A., Puigvert, L., \& Flecha, R. (2011). Critical communicative methodology: Informing real social transformation through research. Qualitative Inquiry, 17(3), 235-245. https://doi.org/10.1177/10778004103 97802

Gómez, J., Latorre, A., Sanchez, M., \& Flecha, R. (2006). Metodologia comunicativa crítica. El Roure.

Gringeri, C., Wahab, S., \& Anderson-Nathe, B. (2010). What makes it feminist: Mapping the landscape of feminist social work research. Affilia: Journal of Women and Social Work: 25(4), 390-405.

Hankok, I. (2002). We are the Romani people. University of Hertfordshire Press.

Hinton-Smith, T., Danvers, E., \& Jovanovic, T. (2017). Roma women's higher education participation: Whose responsibility? Gender and Education, 30(1), 1-18. https://doi.org/10.1080/09540253.2016.1274386

INCLUD-ED Consortium. (2006-2011). INCLUD-ED. Strategies for inclusion and social cohesion in Europe from education (FP6, European Commission).

Jani, J., Osteen, P., \& Shipe, S. (2016). Cultural competence and social work education: Moving toward assessment to practice behaviors. Journal of Social Work Education, 52(3), 311-324. https://doi.org/10. 1080/10437797.2016.1174634

Kroon, A. C., Kluknavská, A., Vliegenthart, R., \& Boomgaarden, H. G. (2016). Victims or perpetrators? Explaining media framing of Roma across Europe. European Journal of Communication, 31(4), 375-392. https://doi.org/10.1177/0267323116647235

Laparra, M. (Coord.) (2007). Situación social y tendencias de cambio en la población gitana. Universidad Pública de Navarra. http://www.fsgg.org/upload/11/95/1.8-LG-1007944_Situacion_social_y_tendencias_ de_cambio_en_la_Comunidad_Gitana.pdf 
Lechuga-Peña, S., \& Lechuga, C. E. (2018). Xicanisma/o and education: Counter storytelling and narratives to inform Latina/o student success. Affilia: Journal of Women and Social Work, 33(3), 300-316. https://doi. org $/ 10.1177 / 0886109917747633$

Martín-Pérez, M., Barrera, V. H., de Andrés, A. L., Jiménez-Trujillo, I., Jiménez-García, R., \& CarrascoGarrido, P. (2015). Predictors of medication use in the Roma population in Spain: A population-based national study. Public Health, 129(5), 453-459. https://doi.org/10.1016/j.puhe.2015.01.028

Melgar, P., Larena, R., Ruiz, L., \& Rammel, S. (2011). How to move from power-based to dialogic relations? Lessons from Roma women. European Journal of Education, 46(2), 219. https://doi.org/10.1111/j.1465-343 5.2011.01477.x

Moghadam, V. (2002). Islamic feminism and its descontents: Toward a resolution of a debate. Signs, 27(4), $1135-1171$.

Oprea, A. (2004). Re-envisioning social justice from the ground up: Including the experiences of Romani women. Essex Human Rights Review 1(1), 29-39.

Padilla, T., González-Monteagudo, J., \& Soria-Vílchez, A. (2017). Roma in higher education: A case study of successful trajectories at the University of Seville. Revista de Educación, 377, 187-211. https://doi.org/10. 4438/1988-592X-RE-2017-377-358

Peeters, K. (2005). Entre tenebres. Gitanos immigrants: Els Rom de l'est d'Europa a Barcelona y el seu accés a l'educació. Fundació Bofill-Finestra Oberta.

Pérez de la Fuente, O. (2008). Mujeres gitanas. De la exclusión a la esperanza. Universitas Revista de Filosofia, Derecho y Política, 7, 109-146. Instituto de Derechos Humanos "Bartolomé de las Casas" de la Universidad Carlos III. https://e-archivo.uc3m.es/bitstream/handle/10016/8495/mujeres_perez_URFDP_2008.pdf? sequence $=1 \&$ is Allowed $=\mathrm{y}$

Reimer, J. (2016). Education, ethnicity and gender. Educational biographies of 'Roma and Sinti' women in Germany. European Journal of Social Work, 19(3-4), 556-569. https://doi.org/10.1080/13691457.2015. 1126557

Sánchez, M. (2005). Estudi sobre la població gitana de Catalunya. Informe final. Direcció Generals de Seveis Comunitaris, Departament de Benestar i Família.

Segovia, C. (2016). Roma women research-Report on Spain. Council of Europe. https://rm.coe.int/ $16806 \mathrm{cb} 07 \mathrm{c}$

Sierra, M., \& Rio, M. A. (2017). Cuando la violencia contra los gitanos se disfraza de ciencia. Contexto y Accion, 111. http://ctxt.es/es/20170405/Firmas/12071/gitanos-minoria-persecucion-violencia-ciencia.htm

Soler, M. (2017). Achieving social impact. Springer.

Sordé, T. (2006). Les reivindications educatives de la dona gitana. Galerada.

Sordé, T., Flecha, R., \& Mircea, T. (2013). El pueblo gitano: Una identidad global sin territorio. Scripta nova. Revista Electrónica de Geografía y Ciencias Sociales, 17(427). http://www.ub.es/geocrit/sn/sn-427/sn427-3.htm

Torres, J. A. (1987). Los gitanos somos una Nacion. Ediciones Romaní, D.L.

Touraine, A., Wieviorka, M., Flecha, R., \& Amaro, M. I. (2004). Conocimiento e identidad. Voces de grupos culturales en la investigación social. El Roure.

Tremlett, A. (2014). Demotic or demonic? Race, class and gender in 'gypsy' reality TV. The Sociological Review, 62(2), 316-334. https://doi.org/10.1111/1467-954X.12134

Turner, B. (2006). The Cambridge dictionary of sociology. Cambridge University Press.

United Nations Educational, Scientific, and Cultural Organization. (2010). Global Education Digest: Comparing education statistics around the world. http://unesdoc.unesco.org/images/0018/001894/189433e.pdf

United Nations World Conference Against Racism. (2001, September 3). NGO forum declaration. Durban. http://i-p-o.org/racism-ngo-decl.htm

Vargas, J., \& Gómez, J. (2003). Why Romà do not like mainstream schools: Voices of a people without territory. Harvard Educational Review, 4(73), 559-590. https://doi.org/10.17763/haer.73.4.k680743 2592612j3 
Weaver, H. N. (1999). Indigenous people and the social work profession: Defining culturally competent services. Social Work, 44(3), 217-225. https://doi.org/10.1093/sw/44.3.217

Woodcock, S. (2010). Gender as catalyst for violence against Roma in contemporary Italy. Patterns of Prejudice, 44(5), 469-488. https://doi.org/10.1080/0031322X.2010.527444

WORKALÓ Consortium (2001-2004). WORKALÓ. The creation of new occupational patterns for cultural minorities. The gypsy case (FP5, European Commission).

\section{Author Biographies}

Ariadna Munté Pascual is professor and researcher at the Social Work Training and Research Section of the University of Barcelona, with a PhD in Sociology. She has 10 years of experience as social worker and her research interests include Roma community, primary care and Roma women.

Irene de Vicente is professor and researcher at the Training and Research Unit and the Group of Research on Innovation in Social Work (University of Barcelona), focused on social work and families. She is $\mathrm{PhD}$ at the University of Barcelona and has experience as social worker in different fields.

Virginia Matulic is professor and researcher at the Social Work Training and Research Section and the Group of Research on Innovation and Social Work (University of Barcelona). She is $\mathrm{PhD}$ at the University of Barcelona and has 18 years of experience as social worker.

Jelen Amador is PhD in Sociology at the University of Barcelona and is now affiliated to the Autonomous University of Barcelona as "Juan de la Cierva" Postdoctoral Researcher. Her research interests include Roma community, Roma women and the overcoming of gender inequalities. 